\title{
Pengembangan E-Modul Matematika pada Materi Perbandingan Berbasis Android
}

\author{
Arviana Ega Irawati ${ }^{1}$, Danang Setyadi ${ }^{2}$ \\ 1,2 Program Studi Pendidikan Matematika, Fakultas Keguruan dan Ilmu Pendidikan, Universitas Kristen Satya Wacana \\ Jl. Diponegoro No. 52-60 Salatiga, Indonesia \\ 202017044@student.uksw.edu
}

\begin{abstract}
One of the PSBB policies from the government in the context of handling Corona Virus Disease 2019 (Covid19), which has a significant impact in the field of education, is regarding school holidays. One of the students' obstacles in implementing PJJ (Pembelajaran Jarak Jauh) is students' lack of motivation and enthusiasm to learn independently. This study aims to determine whether the application media "eMod Banding" is valid for students in comparison material and to determine whether the application media "eMod Banding" can be used widely. This research is a Research and Development $(\mathrm{RnD})$ research or development research with the ADDIE model (Analyze, Design, Development, Implementation, Evaluation). The data collection technique used was a questionnaire validation sheet for the application media "eMod Banding" and a Lembar Kerja Peserta Didik (LKPD). The application "eMod Banding" was tested by the validators, namely mathematics teachers of SMP and SMA / SMK with the final result in data analysis of $85 \%$, which means that the application media "eMod Banding" is declared valid to be used as a learning media for students in comparison material. Based on the results of the student worksheet, $70 \%$ of students get a score of 80-100, which means that the application media "eMod Banding" can be used widely.
\end{abstract}

Keywords: E-Module, Comparative Material, Android, RnD

\begin{abstract}
Abstrak
Salah satu kebijakan PSBB dari pemerintah dalam rangka penanganan Corona Virus Desease 2019 (Covid-19) yang berdampak besar dalam bidang pendidikan adalah tentang peliburan sekolah. Salah satu kendala peserta didik dalam pelaksanaan PJJ (Pembelajaran Jarak Jauh) ini adalah kurangnya motivasi dan semangat peserta didik untuk belajar mandiri. Penelitian ini bertujuan untuk mengetahui apakah media aplikasi "eMod Banding" valid digunakan oleh peserta didik pada materi perbandingan dan untuk mengetahui apakah media aplikasi "eMod Banding" dapat digunakan secara luas. Penelitian ini merupakan penelitian Research and Development (RnD) atau penelitian pengembangan dengan model ADDIE (Analyze, Design, Development, Implementation, Evaluation). Teknik pengambilan data yang dilakukan adalah angket lembar validasi media aplikasi "eMod Banding" dan Lembar Kerja Peserta Didik (LKPD) Perbandingan. Aplikasi “eMod Banding” diuji oleh validator yaitu guru-guru matematika SMP dan SMA/SMK dengan hasil akhir pada analisis data yaitu sebesar $85 \%$ yang artinya media aplikasi "eMod Banding" dinyatakan valid untuk digunakan sebagai media pembelajaran peserta didik pada materi perbandingan. Berdasarkan hasil LKPD siswa, 70\% siswa mendapatkan nilai 80-100 yang artinya media aplikasi "eMod Banding” dapat digunakan secara luas.
\end{abstract}

Kata kunci: E-Modul, Materi Perbandingan, Android, RnD

Copyright (c) 2021 Arviana Ega Irawati, Danang Setyadi

$\triangle$ Corresponding author: Arviana Ega Irawati

Email Address: 202017044@student.uksw.edu (J1. Diponegoro 52-60 Salatiga, Indonesia)

Received 19 January 2021, Accepted 25 May 2021, Published 13 October 2021

\section{PENDAHULUAN}

Dampak penyebaran Covid-19 (Corona Virus Desease 2019) masih terus berlanjut hingga tahun 2021 ini. Salah satu upaya pemerintah untuk mencegah tersebarnya Covid-19 adalah pemerintah mengeluarkan kebijakan Pembatasan Sosial Berskala Besar (PSBB). Kebijakan PSBB ini diatur dalam Peraturan Pemerintah Nomor 21 tahun 2020 tentang PSBB dalam rangka Percepatan Penanganan Corona Virus Desease 2019 (Covid-19) yang ditetapkan sejak tangggal 31 Maret 2020. Salah satu kebijakan pemerintah tentang PSBB ini berpengaruh besar terhadap bidang pendidikan. Kebijakan yang dimaksud adalah kebijakan PSBB tentang peliburan sekolah yang diatur oleh Peraturan Menteri 
Kesehatan No. 9 Tahun 2020 tentang Pedoman PSBB dalam rangka Percepatan Penanganan Covid-19 yang ditetapkan pada tanggal 3 April 2020. Hal tersebut sangat berdampak untuk kegiatan aktivitas sekolah.

Semua kegiatan pembelajaran dilakukan secara jarak jauh. Berdasarkan observasi di beberapa sekolah baik jenjang SD, SMP, maupun SMA/SMK di Kab. Semarang dan Kota Salatiga melakukan proses kegiatan belajar mengajar secara online atau daring. Beberapa kendala dalam proses Pembelajaran Jarak Jauh (PJJ) yang muncul adalah guru kesulitan menyesuaikan materi yang diberikan untuk peserta didik dan guru masih terfokus dalam penuntasan kurikulum, kendala lain yang muncul adalah tidak semua orang tua mampu mendampingi peserta didik belajar mandiri di rumah secara optimal karena harus bekerja ataupun karena kemampuan sebagai pendamping belajar peserta didik (kemdikbud.go.id, 2020).

Ada beberapa cara untuk mengatasi kendala saat peserta didik belajar mandiri di rumah. Salah satu caranya yaitu dengan menggunakan media pembelajaran interaktif yang bisa langsung digunakan oleh peserta didik untuk membantu peserta didik lebih memahami materi pembelajaran dan menghilangkan rasa jenuh peserta didik saat proses PJJ berlangsung. Menurut Hamalik (1980:11) secara umum media adalah semua bentuk perantara yang digunakan manusia untuk menyampaikan atau menyebarkan informasi. Menurut Arsyad (2004:5) pengertian media dalam proses pembelajaran cenderung alat-alat grafis, photografis, atau elektronis untuk menangkap, memproses, dan menyusun kembali informasi visual dan verbal. Berdasarkan pendapat di atas, dapat disimpulkan bahwa pengertian media pembelajaran adalah suatu alat atau suatu perantara antara guru dan siswa untuk membantu guru dalam proses pembelajaran.

Media pembelajaran yang baik juga akan mampu memberikan motivasi dan meningkatkan keterampilan dasar peserta didik (Tinto, 2002). Penggunaan media yang menarik dan tepat akan memusatkan perhatian dan konsentrasi peserta didik saat belajar mandiri di rumah, sehingga meminimalisir pudarnya konsentrasi peserta didik saat memahami materi.

Media pembelajaran berbasis android perlu dikembangkan mengingat banyak peserta didik belajar mandiri dan mengakses tugas sekolah maupun web sekolah dengan menggunakan smartphone. Perkembangan media pembelajaran dengan teknologi dapat mendorong terjadinya perpaduan antara teknologi cetak dan teknologi komputer dalam kegiatan pembelajaran, sehingga modul dapat ditransformasikan penyajiannya ke dalam bentuk elektronik atau e-modul (Elektronik \& Dewi, n.d.)

Modul adalah media atau sarana pembelajaran yang berisi materi, metode, batasanbatasan materi pembelajaran, petunjuk kegiatan pembelajaran, latihan dan cara mengevaluasi yang dirancang secara sistematis dan menarik untuk mencapai kompetensi yang diharapkan dan digunakan secara mandiri (Hamdani, 2011:219). Daryanto mengatakan bahwa tujuan utama dari bahan ajar berbentuk modul adalah pembaca bisa menyerap materi atau bahan ajar secara mandiri (Daryanto, 2013). Pengembangan aplikasi e-modul ini juga diharapkan dapat mempermudah siswa 
untuk belajar mandiri.

Matematika merupakan salah satu bidang ilmu yang penerapannya sering digunakan untuk memecahkan masalah dalam kehidupan sehingga penting untuk dipelajari (Subanji, 2015). Namun, hasil belajar siswa terhadap mata pelajaran ini tergolong rendah khususnya pada materi perbandingan. Presentase siswa yang menjawab benar pada soal perbandingan tergolong rendah dengan presentase sebesar 28.45\% (PUSPENDIK, 2019), sehingga peneliti menggunakan materi perbandingan ini ke dalam aplikasi e-modul yang akan dikembangkan.

Materi perbandingan sendiri memiliki banyak manfaat dalam kehidupan sehari-hari. Materi perbandingan atau rasio dapat digunakan untuk membandingkan besaran suatu benda dengan benda lainnya, besaran benda yang dimaksud bisa berupa panjang, kecepatan, massa, waktu, dan sebagainya (As'ari et al., 2017:6). Contoh lain dari penerapan materi perbandingan ini dalam kehidupan sehari-hari adalah skala peta, perbandingan panjang figura dengan foto tercetak, presentase, dan lain sebagainya.

Aplikasi e-modul berjudul "eMod Banding” yang dikembangkan berisi penerapan materi perbandingan dalam kehidupan sehari-hari, materi perbandingan, contoh soal dan pembahasan, latihan soal, evaluasi, dan tentang creator. Menu "Penerapan dalam kehidupan sehari-hari" berisi tentang penerapan materi perbandingan dalam kehidupan nyata. Menu "Materi" berisi Kompetensi Inti (KI), Kompetensi Dasar (KD), Indikator Pencapaian Kompetensi (IPK), Peta Konsep, dan materi perbandingan itu sendiri dengan dilengkapi beberapa video pembelajaran yang diunduh dari YouTube. Menu "Contoh Soal" berisi contoh soal beserta penyelesaiannya. Menu "Latihan Soal" berisi latihan soal sederhana dengan 10 soal disertai penskoran juga dengan batas waktu pengerjaan soal yaitu 30 menit. Menu "Evaluasi" berisi tentang angket evaluasi media dan penilaian diri siswa setelah menggunakan aplikasi "eMod Banding". Menu "Tentang creator" berisi tentang penjelasan singkat mengenai aplikasi "eMod Banding” dan berisi informasi tentang pembuat aplikasi, yaitu peneliti.

Berdasarkan pemaparan diatas, pengembangan aplikasi "eMod Banding" ini diharapkan dapat digunakan oleh peserta didik sebagai media pembelajaran dan dapat digunakan secara luas. Aplikasi yang dikembangkan ini juga diharapkan dapat membantu peserta didik untuk belajar mandiri selama proses PJJ dilaksanakan.

Ada beberapa penelitian terdaluhu yang mengembangkan e-modul ini sebagai media pembelajaran, ringkasan penelitian dan kesimpulan penelitian yaitu: (1) Tapilouw \& Setiawan, (2008) dengan kesimpulan Pembelajaran dengan menggunakan teknologi dapat meningkatkan pemahaman dan retensi siswa serta dapat membuat siswa termotivasi untuk belajar; (2) Utami et al., (2018) dengan kesimpulan Pengembangan e-modul dapat membantu pembelajaran matematika; (3) Afrianti \& Qohar, (2019) dengan kesimpulan Pengembangan aplikasi e-modul dapat meningkatkan keaktifan siswa; (4) Sulistyawatia et al., (2019) dengan kesimpulan Pengembangan aplikasi e-modul dapat meningkatkan pemahaman siswa melalui belajar mandiri. 


\section{METODE}

Penelitian ini merupakan jenis penelitian pengembangan atau Research and Development (R\&D) dengan produk yang dihasilkan berupa aplikasi "eMod Banding" yaitu aplikasi e-modul berbasis android yang ditujukan kepada peserta didik. Penelitian ini menggunakan pengembangan model ADDIE (Analyze Design Development Information Evaluation). Subyek penelitian pengembangan ini adalah peserta didik kelas VIIB di SMP Negeri 2 Salatiga yang menggunakan media aplikasi “eMod Banding”. Teknik yang digunakan untuk mengumpulkan data pada penelitian pengembangan ini adalah angket untuk penilaian validasi media aplikasi "eMod Banding" dan data hasil LKPD yang dikerjakan oleh peserta didik kelas VIIB di SMP Negeri 2 Salatiga yang menggunakan media aplikasi “eMod Banding”. Data penilaian validasi diperoleh dari lembar validasi media aplikasi "eMod Banding" yang diisi oleh validator dengan memberikan skor pada setiap indikator pada lembar validasi yang diberikan. Proses analisis data kevalidan adalah menghitung presentase setiap sub variabel menggunakan rumus:

$$
P(s)=\frac{s}{N} \times 100 \%
$$

Keterangan: $\mathrm{P}(\mathrm{s})$ = nilai presentase; $\mathrm{S}=$ jumlah skor yang diperoleh; $\mathrm{N}=$ jumlah skor maksimum. Hasil presentase yang diperoleh dari analisis data tersebut akan dikategorikan berdasarkan kriteria penilaian kevalidan media seperti yang ditunjukan pada Tabel 1. Berdasarkan Tabel 1. tersebut media aplikasi "eMod Banding" dikatakan valid jika nilai presentase angket validasi lebih dari 68\%. Media aplikasi "eMod Banding" akan diimplementasikan pada peserta didik kelas VIIB di SMP Negeri 2 Salatiga setelah media direvisi sesuai saran dan masukan yang membangun dari validator. Peserta didik yang telah mengunduh dan menggunakan aplikasi "eMod Banding" akan diberikan LKPD terkait perbandingan dan akan dilihat hasil belajarnya. Sedangkan data hasil LKPD yang diisi oleh peserta didik akan digunakan untuk mengetahui apakah media aplikasi "eMod Banding” yang dikembangkan dapat digunakan secara luas.

Tabel 1. Kriteria Penilaian Kevalidan Media

\begin{tabular}{|c|c|c|}
\hline No & Interval & Kriteria \\
\hline 1 & $81 \%<P(s) \leq 100 \%$ & Sangat valid \\
\hline 2 & $68 \%<P(s) \leq 81 \%$ & Valid \\
\hline 3 & $52 \%<P(s) \leq 68 \%$ & Cukup Valid \\
\hline 4 & $36 \%<P(s) \leq 52 \%$ & Kurang Valid \\
\hline 5 & $20 \%<P(s) \leq 36 \%$ & Tidak Valid \\
\hline
\end{tabular}

\section{HASIL DAN DISKUSI}

Hasil dari penelitian pengembangan media aplikasi "eMod Banding” ini adalah sebagai berikut. Analyze

Tahap analyze, pada tahap ini peneliti telah menganalisis dan mengidentifikasi beberapa penelitian terdahulu tentang pengembangan aplikasi e-modul. Salah satu diantaranya adalah penelitian yang dilakukan oleh Utami et al., (2018) tentang pengembangan e-modul matematika dengan manambahkan RPP di dalam menunya, e-modul ini dibuat untuk siswa sehingga menu RPP tidak perlu 
ditambahkan di dalam e-modul karena RPP untuk guru, sehingga berdasarkan analisis tersebut pengembangan aplikasi e-modul yang akan dilakukan ini tidak ada menu RPP dan hanya berisi Kompetensi Inti (KI), Kompetensi Dasar (KD), dan Indikator Pencapaian Kompetensi (IPK). Peneliti juga menganalisis penelitian terdahulu yang dilakukan oleh Sulistyawatia et al., (2019) dkk pada tahun 2019 tentang pengembangan aplikasi e-modul fisika. Hasil analisisnya adalah tidak ada penjelasan berlanjut tentang menu post-test dan latihan soal sehingga dapat diasumsikan bahwa pre-test, post-test, dan latihan soal yang ada dalam aplikasi ini hanya menggunakan penskoran saja, berdasarkan analisis tersebut peneliti mengembangkan aplikasi e-modul "eMod Banding" dengan menu latihan soal yang dilengkapi penskoran dan batas waktu untuk mengetahui waktu yang dihabiskan peserta didik dalam mengerjakan latihan soal yang diberikan. Kegiatan selanjutnya pada tahap ini adalah peneliti menganalisis materi yang digunakan pada aplikasi e-modul dengan mengakses web resmi dari dinas pendidikan, yang diakses adalah data hasil UN (Ujian Nasional) tingkat SMP pada Tahun Ajaran 2018/2019 dan diperoleh hasil bahwa presentase siswa yang menjawab benar pada soal perbandingan tergolong rendah dengan presentase sebesar 28.45\% (PUSPENDIK, 2019). Berdasarkan analisis tersebut, materi yang digunakan pada aplikasi e-modul adalah materi perbandingan.

\section{Design}

Tahap desain merupakan tahap lanjut dari tahap analisis. Langkah-langkah yang dilakukan oleh peneliti pada tahap ini adalah: (1) membuat alur algoritma aplikasi "eMod Banding"; (2) menentukan Kompetensi Inti (KI); (3) menentukan Kompetensi Dasar (KD); (4) menentukan Indikator Pencapaian Kompetensi (IPK); (5) menentukan peta konsep dan materi perbandingan; (6) mencari dan mengunduh video pembelajaran terkait perbandingan, perbandingan senilai, dan perbandingan berbalik nilai; (7) menentukan soal-soal perbandingan yang akan digunakan pada menu contoh soal dan menu latihan soal; (8) membuat desain background, icon, dan semua komponen yang dibutuhkan untuk aplikasi "eMod Banding" menggunakan software CorelDraw X7; (9) menentukan software yang akan digunakan dan memasang software pada perangkat peneliti, peneliti menggunakan software Smart Apps Creator 3 (SAC) untuk membuat aplikasi "eMod Banding; (10) membuat aplikasi "eMod Banding". Tampilan aplikasi "eMod Banding" dapat dilihat pada Gambar 1. sampai Gambar 15.

\section{Developement}

Tahap developement adalah tahap setelah tahap design dilakukan. Setelah proses pembuatan aplikasi "eMod Banding" selesai yang artinya adalah produk media aplikasi "eMod Banding" sudah dihasilkan, peneliti melakukan proses validasi terhadap aplikasi "eMod Banding". Proses validasi menggunakan instrumen yang telah disiapkan dan telah disetujui oleh dosen pembimbing. Lembar penilaian validasi ini terdiri dari 40 indikator. Validasi dilaksanakan dengan tujuan agar aplikasi yang telah dikembangkan mendapat masukan dari validator yang memang ahli dalam bidangnya dan sebagai bukti bahwa aplikasi sudah layak untuk digunakan dalam penelitian. Selanjutnya, aplikasi "eMod Banding" yang telah dikembangkan, diperbaiki dan disempurnakan berdasarkan masukan dan saran dari para validator. Validator pada penelitian media aplikasi ini adalah Bapak Mahmudi S.Pd., sebagai guru matematika di 
SMP Negeri 2 Salatiga, Bapak Suwasono, S.Pd., sebagai guru matematika di SMP Kristen Satya Wacana Salatiga, Bapak Wahyu Eka M., S.Pd., sebagai guru matematika di SMA Negeri 1 Ambarawa, dan Ibu Dinda Ayu Septiana, S.Pd., dan Bapak Albar Jadmiko Widhy Purwantoro, S.Pd., sebagai guru matematika di SMK Bina Nusantara Ungaran. Ada beberapa saran/masukan dari hasil penilaian angket validasi media oleh validator. Saran/masukan dari validator terdapat pada Tabel 2. Berdasarkan saran/masukan dari validator, media aplikasi direvisi dan tampilan revisi aplikasi "eMod Banding" ada pada Gambar 16.

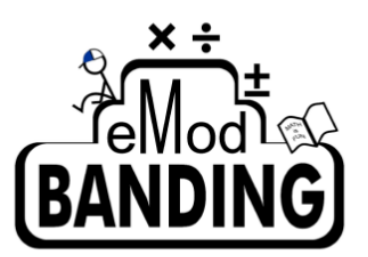

Gambar 1. Tampilan pembukaan

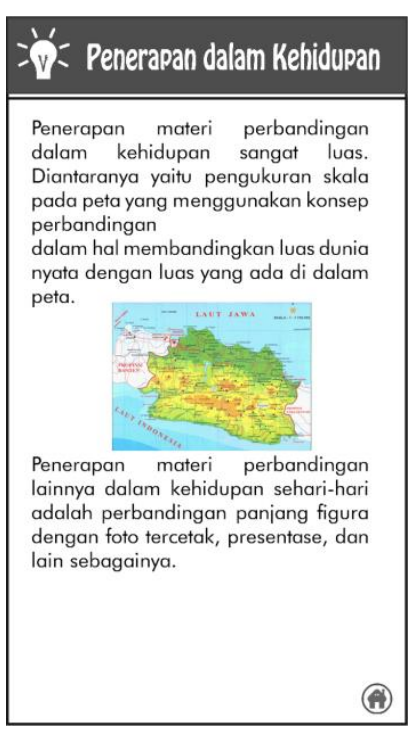

Gambar 4. Tampilan halaman penerapan materi perbandingan dalam kehidupan seharihari.

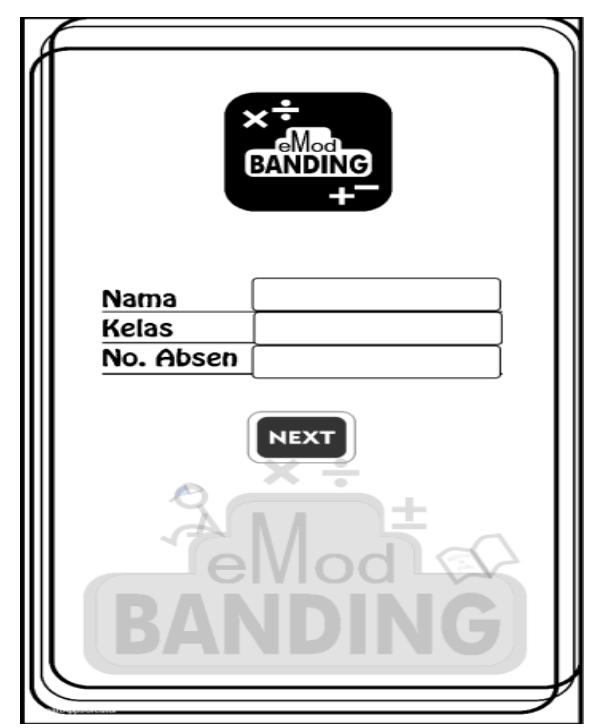

Gambar 2. Tampilan awal setelah pembukaan.

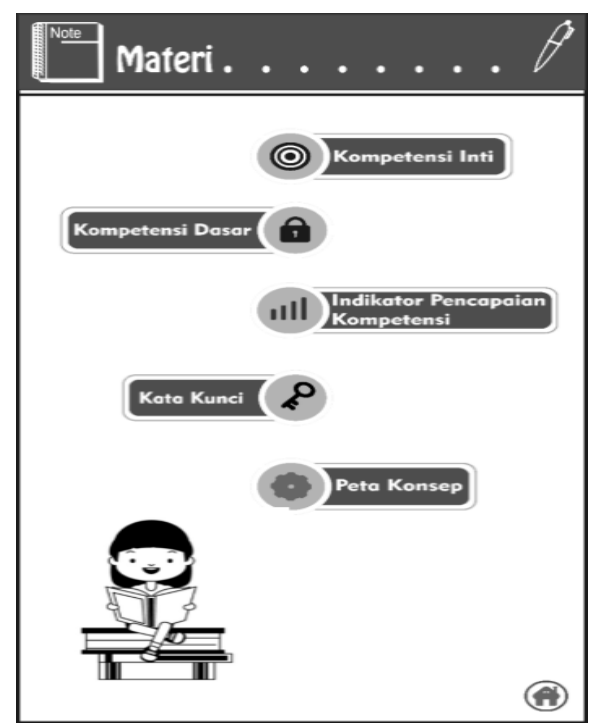

Gambar 5. Tampilan pengantar materi, dilengkapi dengan icon yang menuju materi terkait. Misalnya saat menekan icon Kompetensi Dasar maka akan muncul halaman yang berisi Kompetensi Dasar.
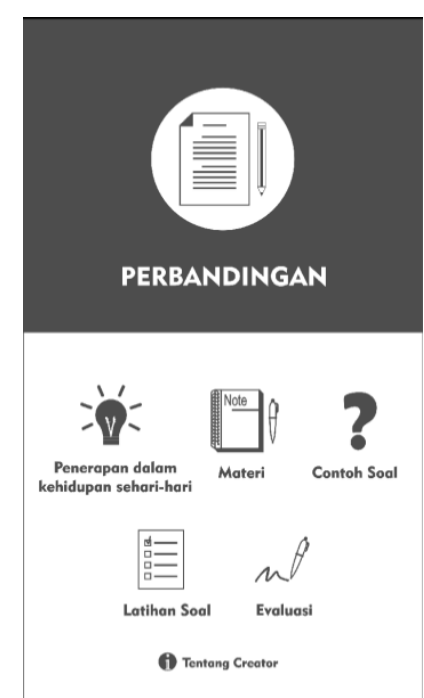

Gambar 3. Tampilan home page atau tampilan menu utama dilengkapi icon utama yang mengarah ke setiap menu.

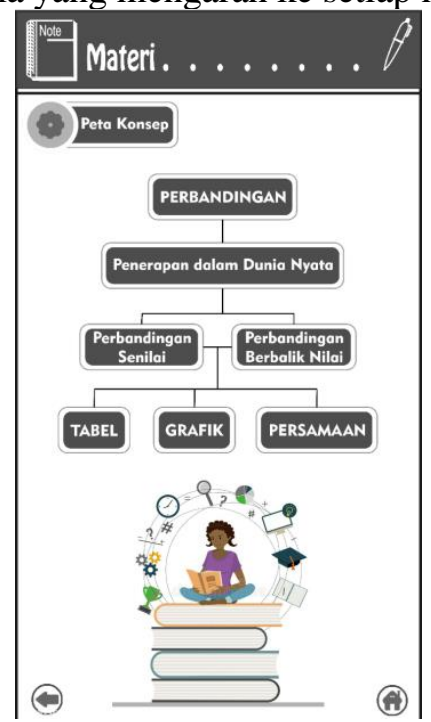

Gambar 6. Tampilan peta konsep materi perbandingan, dilengkapi dengan icon yang menuju materi terkait. Misalnya saat menekan icon perbandingan maka akan muncul halaman materi perbandingan. 


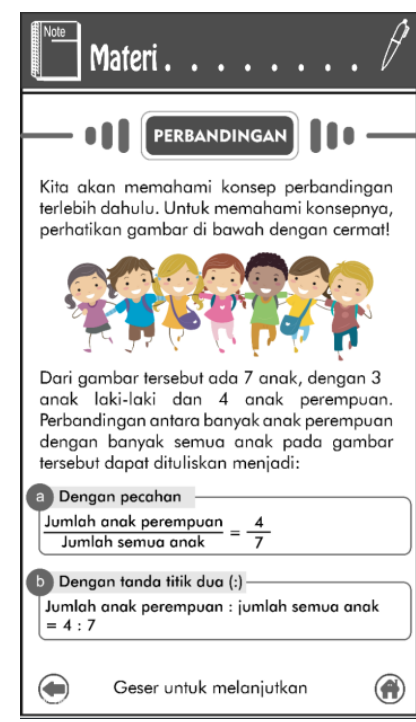

Gambar 7. Tampilan ringkasan materi pengantar perbandingan.

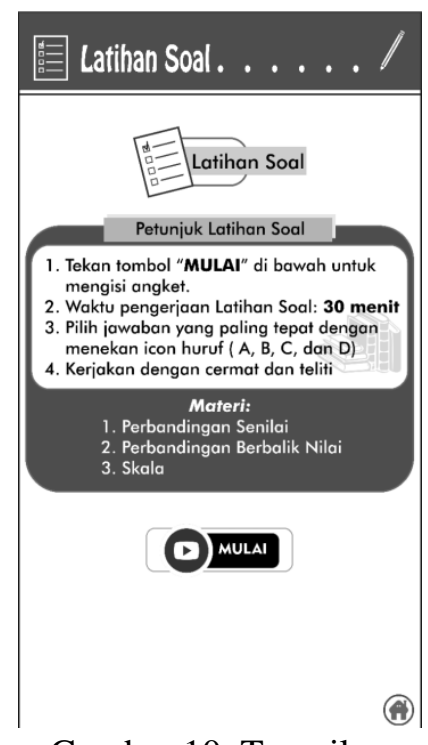

Gambar 10. Tampilan awal latihan soal dilengkapi petunjuk pengerjaan latihan soal dan dilengkapi keterangan materi latihan soal yang akan dikerjakan oleh peserta didik.

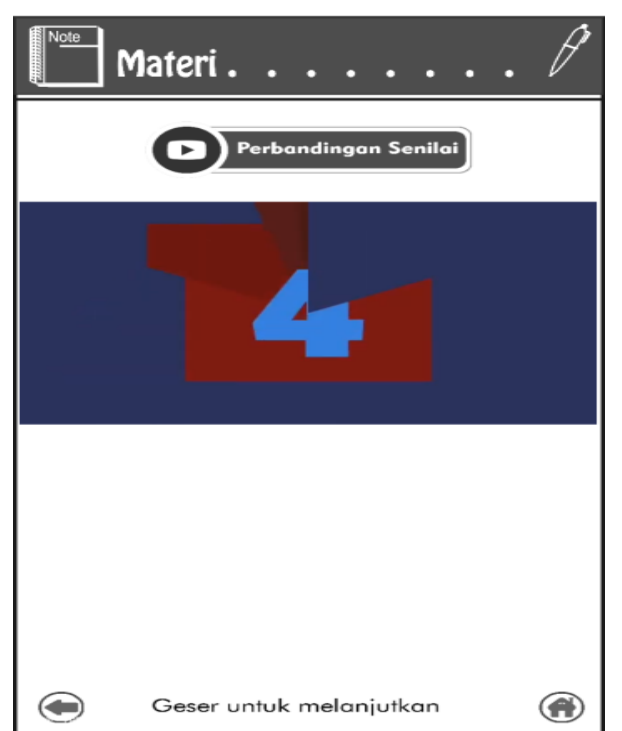

Gambar 8. Tampilan video pembelajaran perbandingan.

\section{Latihan Soal}

\section{Soal 1}

Bangun persegi 1 dan persegi 2 memiliki sisi 8 Bangun persegi 1 dan persegi 2 memiliki sisi 8
$\mathrm{~cm}$ dan $12 \mathrm{~cm}$. Perbandingan luas kedua persegi tersebut adalah.

(A) $1: 2$

(B) $2: 3$

(C) $3: 4$

(D) $4: 9$

Waktu: 1796 Skor: 0

Gambar 11. Tampilan soal latihan soal, dilengkapi dengan skor dan keterangan benar/salah serta dilengkapi waktu (s) keterangan pengerjaan latihan soal (10 soal 30 menit). Jika peserta didik menjawab benar, maka akan ditambahakan 10 poin pada skor, jika salah tidak ada pengurangan nilai dan poin skor tidak bertambah.

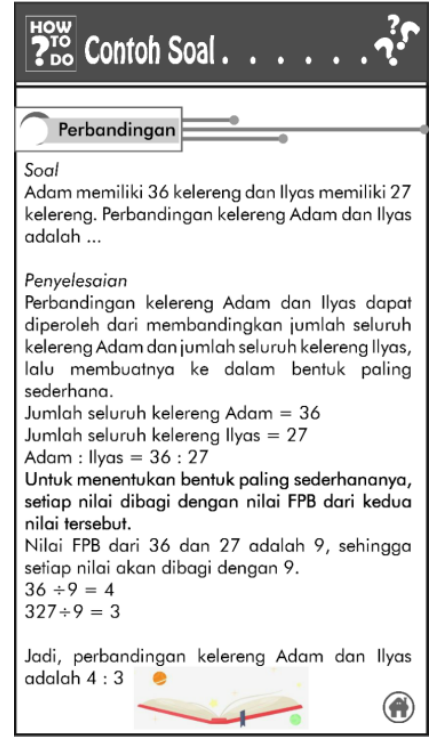

Gambar 9. Tampilan

contoh soal perbandingan dan pembahasan.

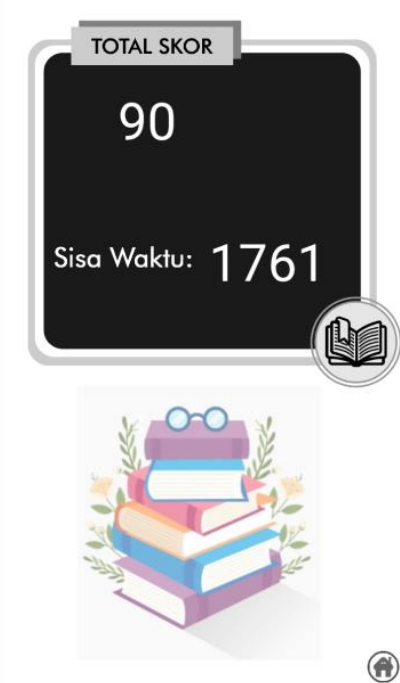

Gambar 12. Tampilan akhir latihan soal dengan keterangan skor akhir dan sisa waktu pengerjaan latihan soal oleh peserta didik. 


\section{Evaluasi . . . . . .}

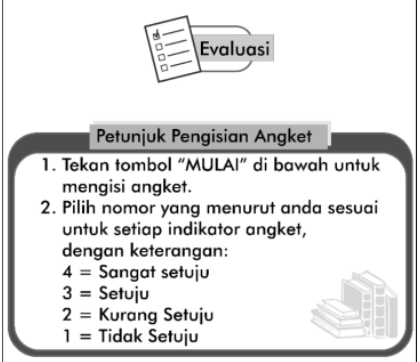

(1) MULAI

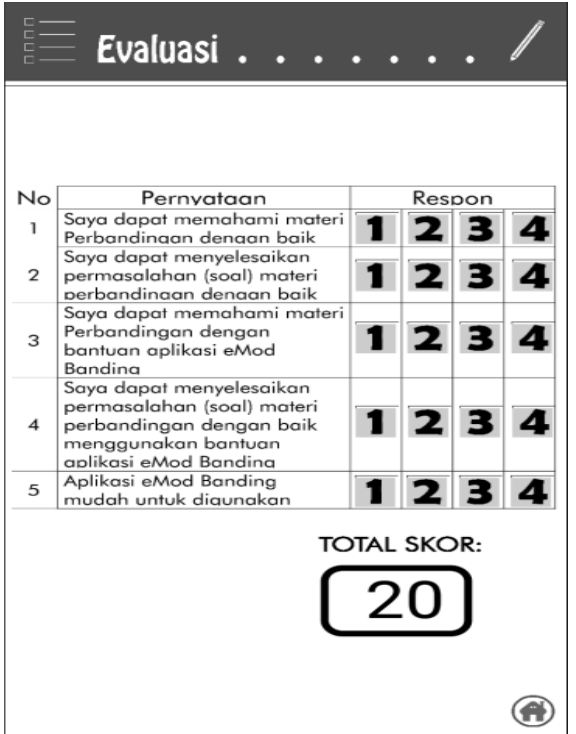

Gambar 14. Tampilan evaluasi/angket yang berisi penilaian diri peserta didik dan penilaian penggunaan aplikasi.

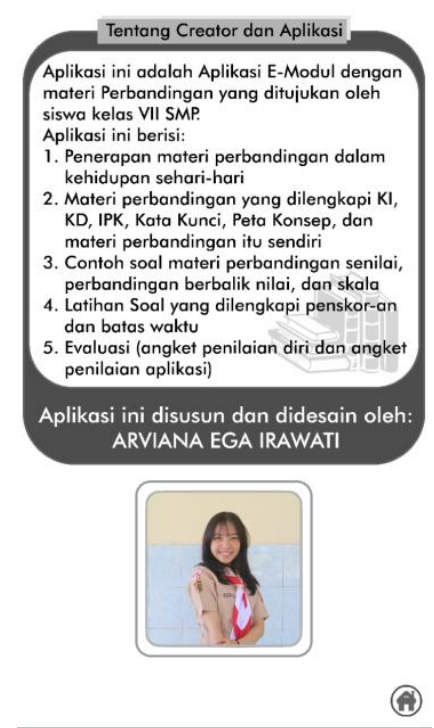

Gambar 15. Tampilan tentang creator, berisi keterangan singkat tentang aplikasi "eMod Banding" dan creator.

Tabel 2. Ringkasan Saran/Masukan dari Validator

\begin{tabular}{|c|c|c|}
\hline \multirow[b]{2}{*}{ Saran/Masukan } & \multicolumn{2}{|r|}{ Tindak Lanjut } \\
\hline & $\begin{array}{l}\text { Diterima/ } \\
\text { Ditolak }\end{array}$ & Keterangan \\
\hline $\begin{array}{l}\text { Memperhatikan penulisan symbol matematika } \\
\text { yang tepat (tanda ":" dan tanda ":-") }\end{array}$ & Diterima & - \\
\hline $\begin{array}{l}\text { Memperhatikan penulisan tanda "?" dan kata } \\
\text { tanya pada soal pilihan ganda dan uraian. }\end{array}$ & Diterima & - \\
\hline $\begin{array}{l}\text { Pada menu latihan soal pengerjaan soal bisa } \\
\text { secara acak }\end{array}$ & Ditolak & $\begin{array}{l}\text { Tidak efisien waktu jika } \\
\text { peserta didik mengerjakan } \\
\text { secara acak }\end{array}$ \\
\hline $\begin{array}{l}\text { Diberi tingkatan soal (tinggi, sedang, rendah) pada } \\
\text { setiap soal di menu latihan soal }\end{array}$ & Diterima & - \\
\hline $\begin{array}{l}\text { Diberi tombol back atau tombol kembali pada } \\
\text { latihan soal }\end{array}$ & Ditolak & $\begin{array}{l}\text { Karena ada keterangan } \\
\text { benar/salah setelah peserta } \\
\text { didik memilih jawaban, jika } \\
\text { diberikan tombol kembali } \\
\text { peserta didik bisa } \\
\text { mengulang-ulang soal untuk } \\
\text { mencari jawaban yang benar. }\end{array}$ \\
\hline $\begin{array}{l}\text { Kategori penilaian penskoran aplikasi pada menu } \\
\text { evaluasi ditampilkan }\end{array}$ & Diterima & - \\
\hline Warna kurang menarik & Diterima & - \\
\hline $\begin{array}{l}\text { Diberi instruksi "geser untuk melanjutkan" di } \\
\text { menu contoh soal }\end{array}$ & Diterima & - \\
\hline $\begin{array}{l}\text { Penjelasan pada contoh soal dan materi dibuat } \\
\text { lebih sederhana }\end{array}$ & Diterima & - \\
\hline $\begin{array}{l}\text { Diberi keterangan interval penilaian angket dan } \\
\text { keterangan penjelasan ulang }\end{array}$ & Diterima & - \\
\hline
\end{tabular}




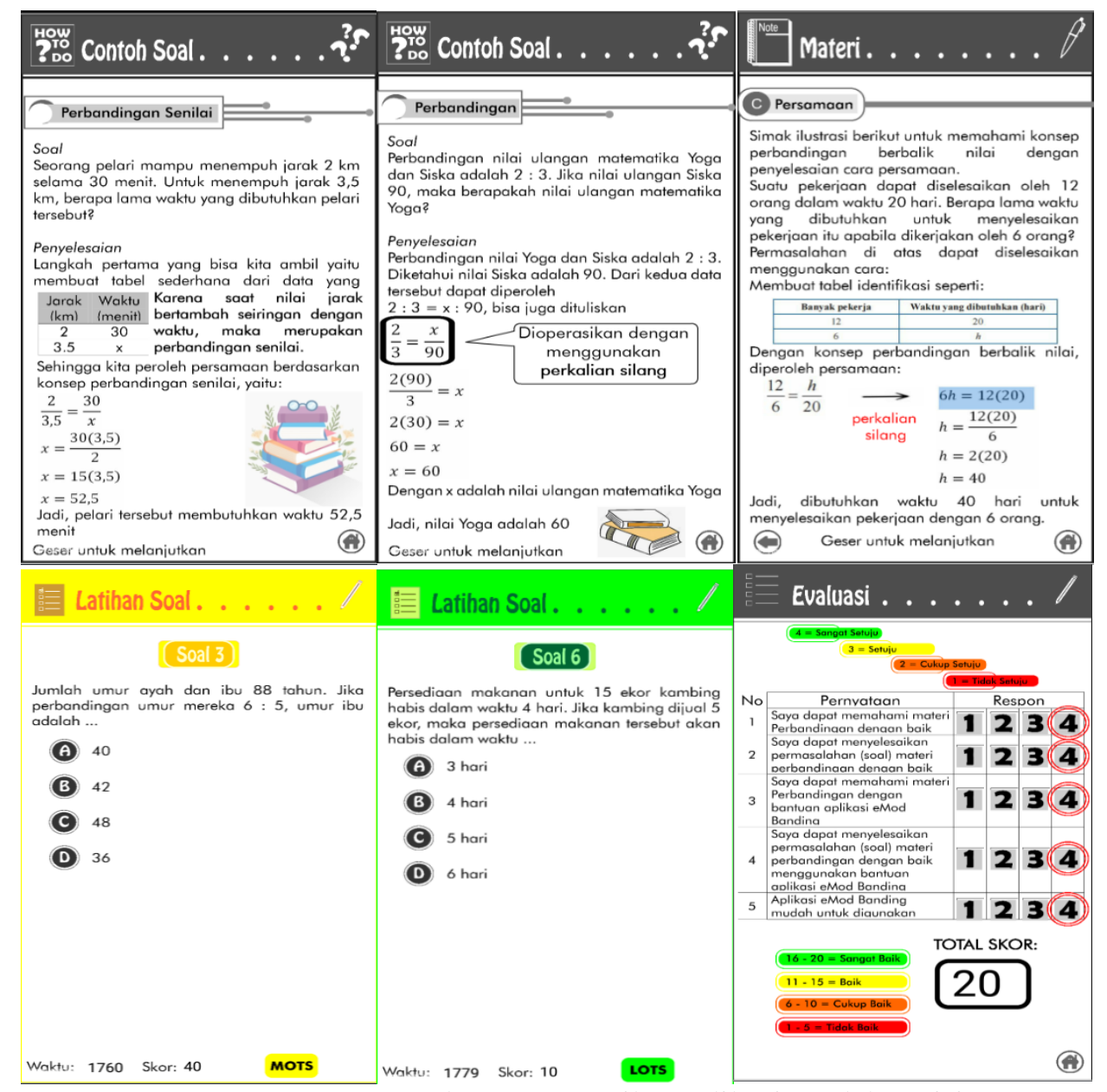

Gambar 16. Tampilan aplikasi setelah revisi

\section{Implementation}

Pada tahap ini, dilakukan proses implementasi media aplikasi "eMod Banding" dan pengolahan data yang didapat dari angket validasi terhadap aplikasi "eMod Banding". Media aplikasi "eMod Banding" diimplementasikan pada peserta didik kelas VIIB di SMP Negeri 2 Salatiga setelah media direvisi sesuai saran dan masukan yang membangun dari validator. Peserta didik yang telah mengunduh dan menggunakan aplikasi "eMod Banding” akan diberikan LKPD terkait perbandingan dan akan dilihat hasil belajarnya. Hasil nilai LKPD yang terkumpul dapat dilihat pada Tabel 3. Sedangkan hasil analisis data kevalidan media aplikasi terdapat pada Tabel 4.

Tabel 3. Hasil nilai LKPD

\begin{tabular}{|c|c|c|}
\hline Nilai & Jumlah Peserta Didik & Presentase \\
\hline $80-100$ & 14 & $70 \%$ \\
\hline $60-79$ & 4 & $20 \%$ \\
\hline $50-59$ & 1 & $5 \%$ \\
\hline$<50$ & 1 & $5 \%$ \\
\hline Jumlah & 20 & \\
\hline
\end{tabular}

Berdasarkan Tabel 3., diperoleh hasil: sebesar 70\% peserta didik mendapatkan nilai 80 - 100; sebesar $20 \%$ peserta didik mendapatkan nilai 60 - 79; sebesar 5\% peserta didik mendapatkan nilai 
50 - 59; sebesar $5 \%$ peserta didik mendapatkan nilai <50. Berdasarkan data tersebut, presentase tertinggi yaitu $70 \%$ peserta didik mendapatkan nilai dengan 80-100 yang artinya media aplikasi "eMod Banding" dapat digunakan secara luas.

Tabel 4. Hasil Analisis Data Kevalidan Media

\begin{tabular}{|c|c|c|c|}
\hline No & Aspek & $\begin{array}{c}\text { Rata-Rata Skor } \\
\text { perolehan }\end{array}$ & Kategori \\
\hline 1 & Kesesuaian dengan tujuan & $86 \%$ & Sangat baik \\
\hline 2 & $\begin{array}{l}\text { Kesesuaian dengan } \\
\text { pembelajaran }\end{array}$ & $84 \%$ & Sangat baik \\
\hline 3 & Praktis, luwes, dan bertahan & $89 \%$ & Sangat baik \\
\hline 4 & Penggunaan & $85 \%$ & Sangat baik \\
\hline 5 & $\begin{array}{l}\text { Kesesuaian pengelompokan } \\
\text { sasaran }\end{array}$ & $84 \%$ & Sangat baik \\
\hline 6 & Mutu teknis & $85 \%$ & Sangat baik \\
\hline \multirow[t]{2}{*}{7} & Novelty & $84 \%$ & Sangat baik \\
\hline & $\mathrm{P}(\mathrm{s})$ & $85 \%$ & Sangat baik \\
\hline
\end{tabular}

Berdasarkan Tabel 4., diperoleh hasil: aspek kesesuaian dengan tujuan memperoleh hasil presentase 86\% dengan kategori sangat baik; aspek kesesuaian dengan pembelajaran memperoleh hasil $84 \%$ dengan kategori sangat baik; aspek praktis, luwes, dan bertahan memperoleh hasil presentase 89\% dengan kategori sangat baik; aspek penggunaan memperoleh hasil presentase $85 \%$ dengan kategori sangat baik; aspek kesesuaian pengelompokan sasaran memperoleh hasil presentase $84 \%$ dengan kategori sangat baik; aspek mutu teknis memperoleh hasil presentase $85 \%$ dengan kategori baik; dan aspek novelty memperoleh hasil presentase $84 \%$ dengan kategori sangat baik. Hasil perolehan rata-rata semua aspek yaitu 85\% dengan kategori sangat baik. Berdasarkan hasil presentase yang didapatkan, maka media aplikasi "eMod Banding" dinyatakan valid karena hasil perolehan presentase lebih dari $68 \%$.

\section{Evaluation}

Aplikasi "eMod Banding” dinyatakan valid untuk digunakan peserta didik pada materi perbandingan dan dapat digunakan secara luas. Aplikasi ini dapat digunakan peserta didik untuk membantu proses belajar mandiri selama PJJ berlangsung. Aplikasi ini membantu peserta didik untuk memahami materi perbandingan. Aplikasi ini masih memiliki kekurangan yaitu latihan soal yang disediakan hanya ada 1 dan aspek tampilan pada aplikasi ini masih perlu dikembangkan menyesuaikan perkembangan karakter peserta didik.

\section{KESIMPULAN}

Berdasarkan hasil penelitian dan pembahasan yang telah diuraikan, maka diperoleh beberapa kesimpulan yaitu: (1) media aplikasi "eMod Banding" pada materi perbandingan untuk peserta didik dikembangkan dengan bantuan software Corel Draw X7 dan Smart Apps Creator 3 (SAC 3) berdasarkan 
tahapan penelitian pengembangan model ADDIE (Analyze, Design, Developement, Implementation, Evaluation); (2) produk yang dihasilkan berupa media aplikasi "eMod Banding" yang ditujukan untuk peserta didik pada materi perbandingan dan telah teruji dan tervalidasi oleh validator. Kevalidan media aplikasi "eMod Banding" ditentukan melalui hasil analisis lembar validasi media aplikasi "eMod Banding". Hasil presentase yang diperoleh yaitu sebesar 85\% dengan kategori sangat valid; (3) media aplikasi "eMod Banding" dapat digunakan secara luas. Saran dari peneliti yaitu: (1) peserta didik dan guru menggunakan aplikasi "eMod Banding" untuk membantu peserta didik dalam belajar mandiri saat proses PJJ berlangsung; (2) proses pengembangan dan desain media aplikasi "eMod Banding" lebih dikembangkan dalam setiap aspek.

\section{UCAPAN TERIMA KASIH}

Ucapan terimakasih dari peneliti yang terdalam disampaikan kepada semua pihak yang ikut terlibat dalam proses penelitian pengembangan aplikasi "eMod Banding", ikut membantu dan ikut serta mendukung berjalannya penelitian dari awal sampai terselesaikannya penelitian ini.

\section{REFERENSI}

Afrianti, R. E. N., \& Qohar, A. (2019). Pengembangan E-Modul Berbasis Kontekstual pada Materi Program Linear Kelas XI. Jurnal Edukasi Matematika Dan Sains, 7(1), 22. https://doi.org/10.25273/jems.v7i1.5288

As'ari, A. R., Tohir, M., Valentino, E., Imron, Z., \& Taufiq, I. (2017). Buku Guru Kelas VII Edisi Revisi.

Elektronik, P. M., \& Dewi, A. C. (n.d.). Pengembangan Modul Elektronik ... (Aditama C. Dewi) 1. 1, $1-7$.

Azhar, A. (2011). Media pembelajaran. Jakarta: Rajawali Pers.

Daryanto. 2013. Media Pembelajaran. Bandung: Satu Nusa

Hamalik, Oemar. (1980). Media Pendidikan. Bandung: Alumni

Hamdani. 2011. Strategi Belajar Mengajar. Bandung: Pustaka Setia

https:// hasilun.puspendik.kemdikbud.go.id/ diakses 3 Januari 2021

https://kemlu.go.id/brussels/id/news/6349/kebijakan-pemerintah-republik-indonesia-terkait-wabahcovid-19 diakses 3 Januari 2021

KEMDIKBUD.https://www.kemdikbud.go.id/main/blog/2020/08/penyesuaian-keputusan-bersamaempat-menteri-tentang-panduan-pembelajaran-di-masa-pandemi-covid19 diakses 3 Januari 2021

Subanji, S. (2015). Peningkatan Pedagogical Content Knowledge Guru Matematika Dan Praktiknya Dalam Pembelajaran Melalui Model Pelatihan Teqip. Jurnal Ilmu Pendidikan Universitas Negeri Malang, 21(1), 106225.

Sulistyawatia, N., Budi, E., \& Siswoyo, S. (2019). Pengembangan E-Modul Fisika Tegas (Tegangan, Regangan, Dan Modulus Young) Berbasis Android Dengan Pendekatan Inquiry Based Learning Pada Materi Elastisitas Untuk Siswa Sekolah Menengah Atas. VIII, SNF2019-PE-151-158. 
https://doi.org/10.21009/10.21009/03.snf2019.01.pe.19

Tapilouw, F., \& Setiawan, W. (2008). Meningkatkan Pemahaman dan Retensi Siswa Melalui Pembelajaran Berbasis Teknologi Multimedia Interaktif. Jurnal Pendidikan Teknologi Informasi Dan Komunikasi, 1(2), 19-26.

Tinto, V. L. (2002). Eprimer-Edu.Pdf (Application/Pdf Object). Ict in Education, 34. http://www.apdip.net/publications/iespprimers/eprimer-edu.pdf

Utami, R. E., Nugroho, A. A., Dwijayanti, I., \& Sukarno, A. (2018). Pengembangan E-Modul Berbasis Etnomatematika Untuk Meningkatkan Kemampuan Pemecahan Masalah. JNPM (Jurnal Nasional Pendidikan Matematika), 2(2), 268. https://doi.org/10.33603/jnpm.v2i2.1458 